\title{
Restoring the Balance between People, Places, and Profits: A Psychosocial Analysis of Uneven Community Development and the Case for Placemaking Processes
}

\author{
Erin E. Toolis
}

Citation: Toolis, E.E. Restoring the Balance between People, Places, and Profits: A Psychosocial Analysis of Uneven Community Development and the Case for Placemaking Processes. Sustainability 2021, 13, 7256 https://doi.org/10.3390/su13137256

Academic Editor: Fernando Brandão Alves

Received: 1 April 2021

Accepted: 20 June 2021

Published: 29 June 2021

Publisher's Note: MDPI stays neutral with regard to jurisdictional claims in published maps and institutional affiliations.

Copyright: (C) 2021 by the author. Licensee MDPI, Basel, Switzerland. This article is an open access article distributed under the terms and conditions of the Creative Commons Attribution (CC BY) license (https:// creativecommons.org/licenses/by/ $4.0 /)$.
Department of Psychology, State University of New York at Old Westbury, Old Westbury, NY 11568, USA; toolise@oldwestbury.edu

Abstract: Recent years have seen a paradigm shift from individualistic, market-based models of community development to more sustainable and human-centered approaches that emphasize inclusion and participation. Yet processes of privatization in the era of neoliberalism threaten these efforts by concentrating profits for elites while impoverishing everyday people and the environments they inhabit, resulting in profoundly uneven access to resources, inclusion, and participation. This analysis examines the psychosocial processes that produce and are produced by these unequal and segregated settings, as well as the causes and correlates of this imbalance in the context of the United States. Then, empirical literature is reviewed exploring the harmful consequences that inequality entails for individual and societal wellbeing, arguing that inequality (a) undermines opportunity by limiting access to resources and constraining upward mobility, (b) undermines community by dissolving trust and cohesion, (c) undermines ecosystems health by accelerating environmental degradation, and (d) undermines democracy by reducing the political power of the non-wealthy relative to the wealthy. Finally, four placemaking principles are proposed as a way to promote more sustainable, equitable, and inclusive community development.

Keywords: placemaking; privatization; economic inequality; community development; social inclusion; sustainability

Processes of privatization in the era of neoliberalism have contributed to growing inequality by prioritizing economic growth over social and environmental wellbeing. This imbalance is driven by top-down, exclusionary models of community development that result in concentrated wealth for elites and impoverishment for everyday people and the places they inhabit. Research is needed to understand the processes and settings that function to resist widening these gaps and instead promote healthier and more equitable, democratic communities for all.

The current paper examines the sources and consequences of exclusion and inequality in community development processes, and advances placemaking as a way to promote equitable and sustainable development. The analysis begins by examining dominant social constructions of the public and the ways in which these constructs have historically limited participation for the majority of community members, especially members of low-status social groups, with a focus on the United States. Next, empirical literature is reviewed that illuminates the harmful consequences of inequality on individual and societal wellbeing, explicating how these divides undermine sustainable development by threatening economic mobility, community, ecosystems health, and democracy. Finally, placemaking processes are proposed as a pathway to sustainable community development by promoting place attachment, community cohesion, and civic participation. The analysis concludes by presenting four principles for equitable placemaking, supported by illustrative exemplars, that reduce barriers to access and participation for historically underrepresented community members.

Psychology has an important role to play in informing community development by illuminating the processes through which individuals and environments mutually 
shape one another [1]. As such, this analysis is grounded in the intellectual traditions of environmental psychology [2-4], cultural psychology [5-7], and community and liberation psychology [8-10], emphasizing a critical, social constructionist, agentic, and transactional approach to understanding the self in society.

\section{Socially Constructing the Public: Implications for Participation and Equity}

Participation in the public realm, and in the places and institutions that make it up, has historically been dominated by elites and limited for the majority of the public. These limits are rooted in a dominant social construction of the public that emphasizes a collection of isolated, passive spectators, characterized as fundamentally irrational, ignorant, and selfinterested [11]. The distinction between elites and the "masses" is not a neutral reflection of reality, but rather a reflection of dominant ideology that serves the interests of those in positions of power-historically occupied disproportionately by white, wealthy men [11].

The social construction of historically disenfranchised groups as inferior is rooted in negative beliefs (stereotypes), attitudes (prejudice), and behaviors (discrimination) [12]. Psychological research shows that low-income groups and people of color are consistently perceived as more animal-like [13,14], stereotyped as low in competence, warmth, and morality, and more likely to be treated with disgust and contempt [15]. The construal of individuals who belong to low-status social groups as essentially distinct from elites affects access to resources in the educational realm, where low-income students are often perceived as less capable [16,17], on the job market, where employers have been found to exclude applicants of color and those with less elite backgrounds from interviews and jobs $[18,19]$, and in the housing market, where discrimination against Section-8 voucher holders [20] and people of color is a common occurrence [21].

Social and economic inequality is also reproduced through policies governing land use and development. For example, the US Federal Housing Administration allowed banks to refuse loans and mortgages in Black neighborhoods from 1934 to 1968 in a practice called redlining, denying African Americans the ability to build equity [22]. Zoning laws have prevented the construction of affordable, multi-family rentals in well-resourced areas and more often locate subsidized housing in primarily low-income neighborhoods [23]. Anti-homeless ordinances, which are prevalent in cities across the US and prohibit sleeping, sitting, standing, congregating, and panhandling in certain public places, are yet another way in which exclusion is institutionalized [24].

Scholars across disciplines have raised critiques of top-down, exclusionary community development practices $[25,26]$. Making decisions and designing interventions to address community problems are often made by formal experts and officials without adequate representation or input from impacted stakeholders. As an example, the Millennium Development Goals (MDGs), proposed by the United Nations in 2000, outlined an ambitious global vision to address humanity's most pressing problems yet were formulated by a select group of experts (largely from the global north) without consultation from groups most directly affected by poverty, hunger, disease, resource depletion, and pollution. Outcomes were defined largely in economic terms, with less attention given to social and environmental considerations, and were prescribed to "developing" countries with aid from "developed" countries. This approach neglected to acknowledge a history of practices and policies enacted by affluent individuals and nations to commodify the land and labor of a marginalized majority for their private enrichment, resulting in unsustainable and vastly divergent outcomes [27].

The Sustainable Development Goals (SDGs), implemented in 2016 to succeed the MDGs, attempted to address these critiques by seeking participation from multiple working groups and large-scale surveys on policy preferences administered to the public [28]. Unlike their predecessors, these goals went beyond a narrow focus on per capita GDP [28]. The updated goals articulated the centrality of sustainability and the critical role of reducing social and economic inequality, although how effectively this vision will be put into practice remains to be seen [29]. 
In sum, the exclusion of impacted stakeholders, and especially those from marginalized groups, from participating in decisions about how community spaces are designed and used has profound implications for the distribution of power and wealth. Inequitable policies and practices by institutions of power, including international bodies, government agencies, financial institutions, schools, and housing authorities, contribute to a two-tiered society that undermines equitable development.

\section{Privatization and the Eclipse of the Public Realm: Implications for Settings and Selves}

Although elite private interests have overshadowed the common good since the founding of the US, the transfer of resources from the public to the private sector, or privatization, has become even more acute in recent decades [30,31]. Processes of privatization accelerated with the rise of neoliberal political economic ideas and practices in the 1970s, which touted free market competition and deregulation as the key to progress [32,33]. The prioritization of economic growth above all else, including the common good, has contributed to the disintegration of the public realm [34,35], or what historian Tony Judt has called "collective impoverishment" [34], and has greatly reduced the quantity and quality of services and institutions dedicated to social and environmental concerns. Tax cuts and subsidies for wealthy individuals and corporations coupled with disinvestment in public infrastructure and the dismantling of social welfare reflected and maintained the dominant belief that redistribution interfered with the free market and was antithetical to growth. The rolling back of public programs continued with cuts to the Environmental Protection Agency, food assistance, income assistance, housing assistance, college assistance, social security disability insurance and supplemental security income, and Medicaid, in addition to work requirements, and "public charge" regulations (which prevent undocumented immigrants from accessing public assistance) issued by the Trump administration [36-38]. These cuts raised barriers to meeting basic needs and exacerbated social and economic divides.

What kind of settings are produced by processes of privatization? Research shows that disinvestment in public infrastructure disproportionately affects neighborhoods where people of color and low-income people live, paving the way for profitable re-investment and, subsequently, gentrification, displacing marginalized residents and creating more segregated, homogenous settings $[30,39,40]$. Other scholars have connected privatization to the construction of "defensible" architecture and "filtered" spaces, which may employ gates, security guards, surveillance cameras, or spikes to limit access for members of the public who are deemed unwanted or unsafe [40-43]. As one example, some U.S. cities have installed "mosquito boxes," which emit a high-pitched sound intended to cause headaches, under bridges to deter unhoused individuals from lingering [44]. In addition, the decrease in government support for public spaces necessitates a greater reliance on private funds, producing settings that are more consumer-oriented, catering to wealthier patrons and prioritizing profitability over civic participation [45]. Overall, these findings illustrate how neoliberal ideology produces and is a product of segregated, market-centered settings.

What does this mean for the selves who occupy these increasingly private settings? As captured by the concept of mutual constitution in cultural psychology [7] and transactionalism in ecological psychology [46], culture, settings, and selves are understood to make each other up. Individuals are not isolated minds, but embodied actors embedded within a cultural and ecological system $[47,48]$. Engagement in neoliberal settings tends to construct the self as an isolated individual, competitor, and passive consumer. These selves are driven by self-promotion and enhancement. The origins of Western values of individualism and autonomy can be traced to a separation from context that accompanies wealth accumulation, extracted from a disenfranchised majority $[5,49,50]$. In this view, freedom is defined as independence from material and social constraints-an escape from the bonds to place and relationship to fellow humans [51]. Achieving this freedom is only possible for a few at the expense of the rest, requiring the production of an alienated, docile majority to exploit, as well as settings that will promote individualism and passivity to make this possible. 
Research suggests that selves in highly individualistic societies experience increasing levels of loneliness and social alienation [52], believed to pose a greater threat to public health than obesity and tobacco $[53,54]$. Market-oriented settings construct selves whose participation is limited to passive consumption [55], and isolation has been found to inhibit collective action and participatory governance [56]. Taken together, research from across the social sciences suggests that privatized settings, and the neoliberal cultural values they inscribe, co-constitute isolated and passive selves, leading to the erosion of power for everyday people.

\section{Consequences of Privatization: Inequality, Fragmentation, and Disengagement}

\subsection{A Society Divided}

The decades following the introduction of neoliberal economic political practices have witnessed a rapid growth in economic inequality [57]. Wealth and income are distributed highly unevenly across the U.S. population, with the wealthiest $10 \%$ earning half of the nation's income, owning 78\% of its wealth, and controlling $84-94 \%$ of business equity, stocks, mutual funds, and trusts [58-60]. The top 1\% alone earned $24 \%$ of the nation's total income and owned $40 \%$ of its wealth [60]. Meanwhile, the wealth owned by the bottom $20 \%$ has a negative net worth, with their debt outweighing their combined assets [59]. With the concentration of wealth at its highest point in decades, the US ranks as one of the most unequal countries amongst industrialized nations [59,61].

The gap between the rich and poor-having reached record levels-is growing wider [62]. In the past three decades, the economy has grown, but only the wealthiest have seen their incomes increase while growth for middle and low-income families has stagnated $[60,63]$. The ratio of wealth for the 90 th percentile to that of the 50th percentile tripled between 1962 to 2013 [59]. During the same period, the ratio of wealth for the 50th percentile to that of the 25th percentile grew tenfold due to the drop in the bottom quartile's net worth [59]. The racial wealth gap also tripled in the last three decades [64]. African Americans own less than eight cents and Latinos own less than ten cents for every dollar owned by whites [64]. This research demonstrates the divergence in wealth and income between the affluent (and especially affluent whites) and the rest in recent decades.

Wealth concentration in the U.S. is more severe than what most members of the population estimate it to be or believe is ideal. In a survey conducted with a large, nationally representative sample of Americans, participants were asked to estimate the distribution of wealth owned by each of the five quintiles and to construct their preferred distribution of wealth [65]. Across all demographic groups, the vast majority significantly underestimated the level of inequality in the U.S. [65]. These findings reflect very low levels of equality and upward mobility for a country that claims to hold these values in high regard [66].

\subsection{Harms of Inequality for Individual and Societal Wellbeing}

Research demonstrates that inequality undermines sustainable development in four key ways: (a) inequality erodes opportunity by limiting access to resources and constraining upward mobility, (b) inequality undermines community by dissolving trust and cohesion, (c) inequality undermines ecosystems health by driving consumption and waste production, and (d) inequality undermines democracy by reducing the political power of the nonwealthy relative to the wealthy.

\subsubsection{Inequality as a Threat to Economic Mobility}

High levels of inequality, coupled with economic and racial segregation, reduce lowincome individuals' control over and access to enriching resources and environments that support opportunities to be healthy, happy, and able to achieve one's definition of prosperity and success. First, income inequality is a proven cause of health problems [67]. It is well-documented that low-income individuals suffer disproportionately from poor health, have diminished access to quality healthcare, and live shorter lives on average than the rich [68]. Research analyzing tax records and mortality data collected from Social 
Security Administration death records discovered that the top 1\% of income earners live longer by 15 years for men and 10 years for women on average than the bottom $1 \%$ [68]. Moreover, this life expectancy gap is rising. In just a little over a decade, between 2001 and 2014 , the wealthiest $5 \%$ of the population gained an extra three years in life expectancy, while the bottom $5 \%$ gained none [68].

An abundance of research also highlights the negative impact that inequality has for psychological wellbeing [69]. Research shows that low-income individuals report higher levels of stress, pain, worry, sadness, anger, and chronic suffering than wealthy individuals [70]. In addition to these findings, an analysis of responses from the General Social Survey between 1974 and 2012 revealed a "gross happiness gap," showing that middle and low-income individuals reported lower levels of happiness in 2015 than in the 1970s whereas the happiness levels of affluent and upper-middle-income individuals have stayed constant [71]. Although perceptions of happiness are subjective and dependent on various cultural and psychological factors, these studies suggest that income is increasingly linked to wellbeing.

The widening of economic and racial divides also undermines academic achievement for low-income youth and youth of color [72]. Research suggests that educational outcomes are increasingly tied to a family's access to private wealth [72]. Whereas middle and low-income families more often must rely on increasingly defunded public resources for their educational enrichment, high-income families can use private resources to access educational products and services such as computers, books, summer camps, private schools, lessons, and travel. In fact, in the midst of cuts to public spending, the gap between what high and low-income families paid for educational goods and services tripled between the mid-1970s and mid-2000s, such that in the mid-2000s, bottom quintile families spent $\$ 1315$ per child on educational enrichment expenditures on average over the course of a year, compared to almost $\$ 9000$ per child spent by top quintile families [73,74]. As education is thought to be the great equalizer and path to upward mobility, these gaps warrant attention.

Although marginalized populations are harmed most by inequality, it is important to note that these disparities also result in broader social ills. In a powerful study conducted by Wilkinson and Pickett [69], internationally comparable data were collected from dozens of rich countries to create an index of health and social problems, finding that across the population, high rates of inequality are strongly correlated with infant mortality, obesity, teen births, mental illness, drug and alcohol abuse, life expectancy, children's educational performance, imprisonment rates, and social mobility. As inequality reinforces the spatial divides that separate people of different races and incomes, everyone pays the price. Taken together, these findings demonstrate the detrimental effects that racial and economic exclusion have for life chances, as well as psychological and physical health.

\subsubsection{Inequality as a Threat to Community}

Neoliberal approaches to development have been critiqued as sacrificing social capital in the narrow pursuit of economic capital, often narrowly defined in terms of gross domestic product (GDP). Increases in economic and spatial divides limit social interaction between diverse groups, undermining community by eroding social trust and cohesion [69]. Thus, not only does inequality detract from physical and mental health, it also increases alienation and hostility between groups.

Robert Putnam's seminal work on social capital, defined as the formal and informal social networks, norms, and relationships that link people together and facilitate cooperation, reciprocity, and trust within and between groups, suggests a decline in social interaction and overall community participation [75]. Moreover, Americans are less trusting of their neighbors than in the past. According to analyses of data from a large nationally representative U.S. sample collected from the General Social Survey, the share of respondents who reported that most people can be trusted dropped from almost half (46\%) in 1972 to just a third (33\%) in 2012 [76]. Higher rates of inequality are also known to be associated with 
an increase in violence and homicides [69]. These rates are particularly high in the U.S. compared to other industrialized democratic nations, though it is important to note that differences in gun control laws and social welfare also likely play a role. Such a decline in social cohesion has a corrosive effect on community and is associated with higher levels of intergroup conflict and poorer economic, health, and wellbeing outcomes for all [77,78].

American society has also lost common ground in the realm of political ideology. A national telephone survey of over 10,000 adults conducted by the Pew Research Center [79] found that political and ideological polarization and partisan antipathy are higher now than at any point in the last two decades. The vast majority of both Democrats and Republicans hold unfavorable views of the opposing party (79\% and $82 \%$, respectively), with many even holding deeply unfavorable views (38\% and $43 \%$, respectively), percentages that have risen in recent decades [79]. Almost a third of adults (36\% of Republicans and $27 \%$ of Democrats) view the other party as a threat to the nation's wellbeing [79]. Research shows that members of the public are more likely to isolate themselves in ideological "echo chambers" where they avoid interaction with people who do not share their views $[77,79]$.

Research also points to a waning in trust in the U.S. government. According to a report by the Pew Research Center, very few members of the public feel that they could trust the federal government always or most of the time (19\%) in 2021, compared to about three-quarters (77\%) in 1964 [80]. Another report found that less than half of respondents reported trusting Congress (13\%), the Supreme Court (40\%), or the Presidency (39\%) a great deal or quite a lot [81]. Research also shows that a large majority of adults believe that most elected officials are dishonest $(71 \%)$ and put their own interests ahead of the country's (72\%) [66]. Confidence in other central U.S. institutions is also quite low, with less than half of respondents reporting a great deal or quite a lot of trust in newspapers $(24 \%)$, television news $(18 \%)$, banks $(38 \%)$, the police $(48 \%)$, and the criminal justice system $(24 \%)$ [81].

A strong civic fabric is grounded in a sense of shared values and shared fate. Yet evidence suggests that neoliberal values of individualism and competition can detract from community and collective civic principles [82]. Unrestrained self-interest on the part of a wealthy few can have an adverse effect on the good of the many. Tax avoidance, for example, practiced by wealthy individuals increases the tax burden on the rest by an estimated 8\% [83]. Numerous studies find that higher income individuals display lower recognition of suffering and feelings of empathy for others [84,85], and are less likely to engage in prosocial or charitable behavior toward others than their lower-income peers [86]. As the wealthy self-segregate, they become detached from the problems of the rest of society (that their practices largely helped to create) and the existence of inequality itself become less visible.

For the non-wealthy, a growing sense of scarcity and malaise diminishes motivation to participate in a society that has largely exploited and abandoned them [58,87]. Highlighting this point, belief in the American Dream is at 64\%: its lowest point in two decades [88]. In addition, inequality stokes intergroup conflict along class lines. According to a Pew Research Center survey of American adults, a full two-thirds of the public believe there are "very strong" or "strong" conflicts between the rich and poor [89].

Trust is necessary for shared social, civic, and economic flourishing. Trust is correlated with decreased crime, increased civic participation, work productivity, and increased health and happiness $[58,90]$. Yet rising inequality has considerably weakened the ties that bind Americans together [58].

\subsubsection{Inequality as a Threat to Ecosystems Health}

Research suggests that equality is a precondition for sustainability, providing a sense of shared responsibility and collective action necessary for maintaining environments that support the health and wellbeing of all [78]. Higher levels of income inequality, on the other hand, are associated with increased levels of resource consumption (such as water, meat, and gasoline) [91], waste generation, greenhouse gas emissions [91,92], and decreased environmental quality, including biodiversity loss [93]. Residents of unequal 
societies practice lower rates of pro-environmental behaviors such as recycling, while business leaders in these contexts are less likely to comply with international environmental agreements and tend to promote policies that maximize consumer and producer surplus, leading to more waste $[78,92]$. A report on wealthy nations' progress in meeting the 17 Sustainable Development Goals found that of all the wealthy nations, the US had one of the highest rates of poverty and inequality between the rich and poor, as well as one of the highest rates of municipal waste generated and production-based greenhouse gas emissions per capita [28].

Wealthy individuals are responsible for a significantly higher share of environmental degradation than low-income individuals. On a global level, the wealthiest $10 \%$ of the population generate over half of carbon emissions and have a carbon footprint that is, on average, 30 times higher than individuals in the poorest 50\% [94]. Meanwhile, the carbon footprint of an individual in the wealthiest $1 \%$ of the global population is over 100 times higher than an individual in the poorest 50\% [94]. Wealthy businesses also play a key role: over half of global greenhouse gas emissions can be traced to just 25 corporations [95].

These broad patterns remain consistent within the US, where individuals living in high income neighborhoods are found to generate $25 \%$ more greenhouse gases than low-income households [96]. Wealthy individuals are more likely to own larger homes, consume more, and dispose of more waste [92]. In fact, income level is a larger predictor of an individual's environmental impact than pro-environment intentions or identity [97].

While elites disproportionately contribute to pollution and climate change, the negative consequences disproportionately affect marginalized communities within and across nations. On a global level, research demonstrates that low-income countries bear the brunt of the harmful effects of climate change, including increased exposure to flooding and erosion driven by sea level rise, salinity intrusion, mudslides, drought, heatwaves, and water scarcity $[98,99]$. Research in the US illustrates that communities of color and lowincome communities are exposed to higher levels of air, water, and soil pollution and closer proximity to treatment, storage, and disposal facilities [100,101]. Differential exposure to environmental hazards plays a key role in driving race and class-based health disparities, including increased rates of cancer, asthma, infant mortality, and premature death [100].

In rolling back environmental regulations and widening the gap between the rich and poor, neoliberal policies have allowed privileged groups to distance themselves from the settings that they pollute and retreat to clean, resource-rich environments for their private use $[102,103]$. These segregated, affluent settings in turn shape the inhabitants' psyches, promoting independence through "freedom from constraint and abstraction from context" ([104]; p. 198). Research demonstrates that this worldview privileges and is privileged by individuals from higher socioeconomic backgrounds [105,106]. Those in power often view competition and individual achievement as key to community development. However, this ethos neglects the role that labor and resources from marginalized communities have played in the wealthy's ability to accumulate capital, and may undermine interdependence and cohesion, further harming marginalized communities and worsening inequality [104].

\subsubsection{Inequality as a Threat to Democracy}

Not only does inequality undermine opportunity, fracture community, and degrade ecosystems health, it widens the gap between everyday people and the political systems and policies that shape their lives. Wealth and political power are tightly interlinked: wealth can be used to wield power in politics through lobbying and campaign financing, and power can be used to concentrate wealth [107]. As wealth becomes more concentrated, so does power.

The erosion of faith in government and political systems contributes to political disengagement by everyday members of society. An analysis of cross-national surveys conducted across wealthy, industrialized, democratic nations found that greater economic inequality is associated with lower interest in the issues being discussed by politicians, lower frequency of political discussion, and decreased voting by the non-wealthy [108]. Voter turnout in 
the US lags behind most other OECD nations $[109,110]$ and participation in elections is strongly related to income and education level [111,112]. Low-income constituents are also less likely than high-income constituents to donate to political campaigns, volunteer for campaigns, or send letters or emails to elected officials [113]. Research finds that organized interest groups and lobbyists are less likely to mobilize on the behalf of low-income voters' interests [113]. Consequently, the wealthy exert a disproportionate influence on politics, who use that influence to oppose redistribution and further concentrate wealth $[109,114]$.

A survey conducted by the Pew Research Center [115] found that $40 \%$ of respondents believed that democracy is not working too well or not at all well. Over three-quarters (76\%) believed that the government is run by a few big interests looking out for themselves and only $21 \%$ believe it is run for the "benefit of all the people" [115]. Less-educated respondents are less likely to believe that voting is a way to have a say in governmental decisions [115]. A majority (61\%) feel that significant changes are needed in the fundamental design and structure of the government. This percentage is highest amongst respondents who identify as Black (70\%) and Hispanic (76\%) [115]. The government has also received low ratings for helping people get out of poverty, ensuring access to healthcare, and ensuring access to a quality education [116].

How accurate is the belief that democracy in the U.S. is not working well? An analysis by Gilens [114] shows that when low and middle-income groups' preferences diverge from high-income groups, policy only responds to the preferences of the high-income group-yet another trend that has amplified in recent decades. These findings add to a growing body of literature showing that U.S. federal policies tend to mirror the interests of the top quintile of Americans more closely than low and middle-income citizens [117,118]. It is important to note that almost half (44\%) of Congress is composed of millionaires [114].

This bias toward the interests of the top poses a problem for representational equality and results in anti-redistributive policies. Although the extremely wealthy are shown to be more liberal than low and middle-income constituents on social issues such as abortion and gay marriage, they are far more conservative on economic policies and issues of social welfare [114,117]. For the most part, everyday Americans favor a stronger public sphere in which the government plays a role in ensuring access to a living wage, quality education, health care, social security, and public infrastructure (e.g., roads) for everyone. Elites, on the other hand, advocate for a stronger private sphere with a deregulated market, lower corporate taxes, privately run health care and social security, and school vouchers [114]. Because the voices of elite individuals and corporations, aided by large donations and policies like Citizens United, speak the loudest and have the least need for shared resources, the public realm is steadily declining [119].

Recent literature suggests that democracy in the United States and European nations is in trouble. Foa and Mounk [120] theorize about the "signs of deconsolidation," warning that democracy can unravel without sufficient support. According to their analysis of data from the World Values Survey between 1995 and 2014, there has been an increase in the proportion of the American public (along with residents of other longstanding democratic nations) who feel that the democratic political system is a bad or very bad way to run the country. Between 1995 to 2011, the percentage of those who believe it is better to have a strong leader who does not have to bother with parliament and elections rose from $24 \%$ to $32 \%$, and the fraction of those who believe it would be a good or very good idea to have military rule rose from $6 \%$ to $17 \%$ [121]. This rise in antidemocratic viewpoints has been most marked amongst the wealthy [121]. Although some scholars in political science and economics note that longstanding democracies tend to be fairly stable and that high inequality does not necessarily predict the complete collapse of a democracy, inequality is widely agreed to be profoundly detrimental to democracy and the fulfillment of civil rights, and worthy of greater attention [122,123]. 


\section{Placemaking as a Tool to Promote Public Participation and Inclusion}

In an era of private affluence and public impoverishment [34] with escalating levels of economic inequality [59], economic segregation [124], loneliness [52], environmental degradation [103], and antidemocratic attitudes [120], attention to bottom-up community spaces is needed. Settings that facilitate community and participation are central to human development and wellbeing $[125,126]$.

Placemaking holds potential for fostering resistance to neoliberal processes of privatization by facilitating place attachment, sense of community, civic responsibility, and civic engagement [127]. I now turn to examine how participation in public spaces and institutions that have historically been created by and for elites can be accessed and transformed by the broader public so as to better promote equity and democratic engagement.

First, in facilitating place attachment, contributing to a sense of embeddedness and bondedness to place, placemaking runs counter to processes of privatization characterized by the commodification of place. Commodification occurs when a good is constructed as an object to be sold or traded [128]. While public interests conceptualize place and its associated resources by their use value, or ability to meet material needs and support community values and activities, private interests conceptualize place in terms of exchange value, or ability to generate profit [129]. An attachment to place asserts use value over exchange value, resisting the neoliberal market logic that incentivizes environmental degradation and disinvestment in public places and programs [130].

Second, in facilitating a sense of community and civic responsibility, placemaking resists the alienation that stems from dominant neoliberal values of hyper-individualism and self-reliance. Cultivating a sense of connectedness and belonging to other individuals in a shared place and a developing a commitment to collective welfare is critical for solidarity and cooperation [131,132]. Research also suggests that social capital contributes to higher quality intergroup contact conditions and leads to more positive attitudes towards outgroups [133], paving the way for more inclusionary social structures and policies. Whereas fragmentation and segregation degrade opportunities for collective knowledge and restrict access to resources and social life for marginalized communities, sense of community and civic responsibility provide an important pathway to collective mobilization [134].

Finally, in facilitating intentions for civic engagement, placemaking processes resist the passivity and depoliticization associated with privatized settings. Scholars suggest that everyday environments are rarely designed to be responsive to the needs and interests of everyday people $[41,45,135]$. Instead, they are frequently designed to avoid uncertainty and minimize the possibility of encountering difference [4,43]. Public participation is reduced to passive observation and consumption, while active decision-making is left to policymakers, planners, and investors. Environmental psychologist Reed [4] argued that our environments are becoming increasingly automatic, prescribed, and pre-packaged in order to "fit people into place" for the sake of productivity and control, rather than respond to the needs and assets of their inhabitants. He writes, "In urban, rural, and suburban American, we are decreasingly capable of organizing environments that afford either a supportive surrounding for our work or a convivial surrounding for other forms of human interaction. Worse, few of us have had the experience of trying to make and shape such places; therefore, fewer and fewer of us cherish the hope that we might work toward the goal of making better places" [4] (pp. 66-67).

\section{Effective Placemaking in Practice: Principles and Exemplars}

While the concept of placemaking has been around since the 1970s, calls have increased in recent decades to shift from expert-led spatial design and planning to more collaborative, bottom-up placemaking processes centering local stakeholders [136]. A growing body of academic literature from diverse disciplines, spanning architectural studies, spatial planning and design disciplines, social sciences, and the arts, has begun to shed light on the mechanisms that citizens use to access and transform the places where they live and work. This empirical and theoretical research has advanced our understanding of these activities 
by explicating the forces that spur placemaking (e.g., needs-based, opportunities-based, and assets-based) [137], theorizing the psychosocial processes by which placemaking can facilitate critical consciousness and empowerment [127], and detailing case studies illuminating how design professionals can work collaboratively with residents [138].

Despite the inclusive potential of placemaking, it is important to point out that these processes are often highly contested. Critical scholars have noted the language of placemaking is easily co-opted by private interests, masking an agenda of gentrification by functioning to increase value through the attraction of wealthy consumers and residents [139]. In emphasizing a generic concept of "community," placemaking initiatives can gloss over power imbalances and considerations of who is included and excluded from participation. This analysis advances four key principles to promote participation and inclusion in placemaking practices: (a) the need for representation and participation from local communities in planning and implementation, (b) a commitment to increase access to resources for marginalized communities, (c) advocacy for redistributive public policies, and (d) attention to environmental sustainability. Each principle is explored below, accompanied by illustrative examples.

\subsection{Representation and Participation from Local Communities in Placemaking Planning and Implementation}

Equitable placemaking initiatives promote representation and participation from local communities, with an emphasis on amplifying the voices of marginalized residents. Decisions are often made by experts (city officials, planners, architects, etc.) with little to no consultation from impacted stakeholders. The planning and implementation of placemaking initiatives must include a consideration of impacted stakeholders' knowledge, needs, and assets.

One result of the exclusion of local stakeholders from shaping the places where they live and work is the erasure of the histories of marginalized communities from the public landscape. Recent years have drawn increased attention to legacies of racism in American public art, statues, and monuments [140]. Effective placemaking initiatives can draw attention to neglected figures and stories. One example is provided by Paper Monuments, a participatory New Orleans-based public art and history project with the mission of imagining new monuments for the city that highlight marginalized narratives. The team holds pop-up events and commissions and displays posters around the city to celebrate the untold stories of local activists, historians, and residents [141].

Inclusive placemaking initiatives also consider questions of property ownership and governance. While private investments can provide much needed resources for development, these efforts are subject to market fluctuations and are not necessarily accountable to the needs and wants of a community. Co-operative placemaking initiatives that provide pathways to public control of community spaces provide critical protection against co-optation by private interests [142]. Community land trusts, in which land is owned by a nonprofit organization on behalf of a community, offer one model for providing secure, affordable, collective property ownership that involves democratic, broad-based participation from local stakeholders [143]. The Dudley Street Neighborhood Initiative, created in 1984 by residents of the Greater Boston area [144], provides an illustrative example of a placemaking initiative that has successfully utilized a community land trust to enable local communities to revitalize their neighborhood while resisting processes of gentrification. The Dudley Street Neighborhood Initiative has transformed abandoned spaces into parks, playgrounds, gardens, and affordable housing, while maintaining the residents' ability to inform and control those development processes and ensuring that any capital generated benefits the community. In these ways, placemaking can play a role in strengthening the rights and voices of local communities.

\subsection{Commitment to Increase Access to Resources for Marginalized Communities}

Equitable placemaking initiatives should serve to increase access to resources for marginalized communities. While economic and racial segregation exclude low-income 
communities and communities of color from nutritious food, clean air and water, transportation, green spaces for play and exercise, and educational resources, activities that facilitate access to and control over these resources can play a valuable role in combatting inequality. An example of a placemaking initiative seeking to increase access to green space is provided by PARK(ing) Day, which originated in San Francisco and now takes place in cities across the globe [145]. PARK(ing) Day is an annual grassroots event in which artists and activists convert metered parking spaces into temporary public parks to demonstrate the need for more public places and serve the needs of the given community, whether by offering seating, political seminars, or bike repair workshops [145].

Placemaking initiatives can also promote food justice. Community garden projects, such as Green Guerillas in New York City [146] and the Ron Finley Project in South Central Los Angeles [147], work to transform underutilized spaces in neighborhoods classified as food deserts to grow fresh, affordable produce. These community-driven, place-based transformations work to rejuvenate communities by combatting disinvestment and strengthening the health, wellbeing, and sovereignty of local residents.

Finally, placemaking initiatives can promote access to educational enrichment. Public institutions such as museums and libraries can serve as valuable platforms for these kinds of initiatives. For instance, the Uni Project works to transform streets and playgrounds in under resourced areas into pop-up reading rooms and art spaces in order to address achievement gaps between children in high- and low-income areas [148]. These examples highlight how placemaking can work to close rather than exacerbate resource disparities.

\subsection{Advocacy for Redistributive Public Policies}

Equitable placemaking initiatives are most effective in concert with redistributive public policies. Projects with the aim of "renewal," "regeneration," or "beautification" hold value in making disinvested or underutilized spaces more vibrant, safe, and livable, but can result in an influx of wealthier residents and consumers, driving up property values and ultimately paving the way for gentrification and inequality [139]. It is vital that placemaking participants advocate for measures such as strong anti-eviction laws, public housing, and rent control to protect and promote the availability of affordable housing for lower income residents and protect against the displacement of existing community members in an area undergoing redevelopment. Placemaking initiatives should also consider the law enforcement and surveillance policies that will govern the space, taking care to avoid "broken windows" policing tactics that target "quality of life" or "nuisance" crimes, which often work to filter lower income community members and people of color out of resource-rich spaces $[41,42]$.

There are several ways that communities can pursue opportunities to protect vulnerable populations and places. One strategy is to advocate for planning authorities to adopt measures that recognize and retain important local sites. For example, in recognition that LGBTQI+ venues were central to the fabric of the city and under threat of decline due to redevelopment, the city of Westminster in the U.K. formulated the "Soho Special Policy Area" in their 2019-2040 city plan to preserve the character and history of LGBTQI+ sites [149].

Community murals represent another place-based mechanism for drawing attention to local concerns and advocating for social change. For instance, in 2016 the New York City Housing Authority partnered with Groundswell, a community arts organization in Brooklyn, to work with residential youth to create murals at five housing projects, focusing on social issues such as over-policing in communities of color [150]. This initiative provided jobs to local youth, improved the quality of the physical environment, and drew public attention to policy issues that need to be addressed in the community.

\subsection{Attention to Environmental Sustainability}

Equitable placemaking initiatives must center considerations of environmental sustainability. Placemaking processes facilitate bonds between people and their environments, cultivating a sense of pride and investment in local places as well as a deepened awareness 
of the interdependence between communities and their ecological context. Placemaking initiatives can help to build more environmentally sustainable communities by improving public transportation as well as greenways for pedestrians and cyclists, protecting green spaces, creating parks, and incorporating environmentally friendly materials and renewable energy sources into spatial design. For example, the City Repair Project, based in Portland, Oregon, brings together community members to promote sustainability through installing permaculture-based ecological landscaping elements throughout the city, such as pollinator habitats and community gardens, as well as building benches and other structures from natural, renewable materials [151]. Eco-communities, such as Christie Walk, a residential community in Adelaide, Australia, founded in 1999, exemplify a commitment to environmental sustainability in their design, materials, and construction [152]. Christie Walk minimized its ecological footprint through the use of recycled and nontoxic building materials, energy and water efficient appliances, the use of solar power, and the construction of gardens [152].

Taken together, these principles and examples highlight the role that placemaking can play in facilitating participatory, inclusive processes and outcomes that work to reduce inequality and promote social and ecological wellbeing.

\section{Placemaking Limits and Challenges}

Despite the benefits outlined here, placemaking processes are not without limits and obstacles. Increasing representation and participation from marginalized communities can be challenging when such community members face barriers such as economic precarity, long work hours, and isolation. The erosion of trust between marginalized communities and public institutions and officials, fueled by legacies of state-sanctioned violence, government inaction, and mismanagement of resources, can undermine opportunities for collaborative partnerships [153]. A lack of cohesion, which can result from power inequalities, spatial segregation, and cultural and language divides, can complicate cooperation between stakeholders, who may often hold different and sometimes even opposing interests, needs, and values. It is also the case that conflict can arise within communities, which are themselves never monolithic but heterogeneous.

It is important to note that placemaking efforts are often nested within broader municipal, state, federal, and international contexts in which undemocratic, anti-redistributive policies may be operating, which can suppress or co-opt participatory efforts. In addition, placemaking initiatives must often confront bureaucratic rules and regulations in addition to challenges in accessing funding, especially in the wake of federal, state, and local budget cuts [153]. Finally, tensions can emerge between social, environmental, and economic priorities (e.g., between development and conservation). Confronting these challenges requires a commitment to partnerships, long-term planning, and ongoing communication, reflection, and evaluation [153].

\section{Conclusions}

The privileging of private elite interests over investment in public places and resources has contributed to increasingly unequal, segregated, consumer-oriented, polluted settings, inhabited by increasingly alienated, passive, and discontented selves. Research is needed to better understand and address the growing divides that erode opportunity, community, ecosystems health, and democratic participation, especially for low-income individuals and people of color who have shouldered a disproportionate share of the burden.

I have argued that the exclusion of the majority of the public from authentic participation has historically been justified by a social construction of the public as untrustworthy and incapable of making informed decisions about their own lives. The hierarchical distinction between the "masses" and "elites" has served to disenfranchise people of color and low-income people to prevent redistribution, so that wealth and decision-makingand, consequently, opportunities for wellbeing-are not shared in common across the population but concentrated in highly uneven ways $[69,114]$. 
In contrast, the concept of placemaking conceives of everyday community members as experts with valuable knowledge and lived experience who have a right to access and transform the places they inhabit $[153,154]$. This conception resists the dominant construction of the public as incapable, ignorant, and in need of control, and enables the possibility for residents to practice active participation. Placemaking can pay the way for resisting privatization, amplifying the input of community members who have been historically underrepresented in decision-making, and considering the value of public institutions and spaces for civic life. To advance equity, effective placemaking must incorporate the expertise and input of local stakeholders, increase access to resources for marginalized communities, advocate for redistributive policies, and center considerations of environmental sustainability. These processes illustrate the potential of local, experiential, bottom-up, community-oriented settings to constitute more rooted, dialogic, socially responsible, active members of the public, who can in turn shape those settings to be more responsive to their needs and interests.

Funding: This research received no external funding.

Institutional Review Board Statement: Not applicable.

Informed Consent Statement: Not applicable.

Data Availability Statement: Not applicable.

Acknowledgments: The author would like to thank Phillip Hammack, Heather Bullock, and Gina Langhout for their feedback on an earlier version of this paper.

Conflicts of Interest: The author declares no conflict of interest.

\section{References}

1. Jaipal, R. Psychology at the Crossroads: Sustainable Development or Status Quo? Psychol. Dev. Soc. 2017, 29, 125-159. [CrossRef]

2. Barker, R.G. Ecological Psychology: Concepts and Methods for Studying the Environment of Human Behavior; Stanford University Press: Stanford, CA, USA, 1975; ISBN 978-0-8047-0658-2.

3. Gibson, J.J. The Ecological Approach to Visual Perception; Psychology Press: New York, NY, USA, 2015; ISBN 978-1-84872-578-2.

4. Reed, E. The Necessity of Experience; Yale University Press: New Haven, CT, USA, 1996; ISBN 978-0-300-06668-5.

5. Adams, G. Context in Person, Person in Context: A Cultural Psychology Approach to Social-Personality Psychology. In The Oxford Handbook of Personality and Social Psychology; Deaux, K., Snyder, M., Eds.; Oxford University Press: New York, NY, USA, 2012; pp. 181-208. ISBN 978-0-19-539899-1.

6. Hammack, P.L. Narrative and the Cultural Psychology of Identity. Personal. Soc. Psychol. Rev. 2008, 12, 222-247. [CrossRef]

7. Shweder, R.A. Cultural psychology-What is it? In Cultural Psychology: Essays on Comparative Human Development; Stigler, J.W., Shweder, R.A., Herdt, G., Eds.; Cambridge University Press: New York, NY, USA, 1990; pp. 1-46.

8. Freire, P. Pedagogy of the Oppressed, 30th ed.; Continuum: New York, NY, USA, 2000; ISBN 978-0-8264-1276-8.

9. Martín-Baró, I.; Aron, A.; Corne, S. Writings for a Liberation Psychology; Harvard University Press: Cambridge, UK, 1994; ISBN 978-0-674-96246-0.

10. Rappaport, J. Empowerment Meets Narrative: Listening to Stories and Creating Settings. Am. J. Community Psychol. 1995, 23, 795-807. [CrossRef]

11. Gone, J.P. Is Psychological Science A-Cultural? Cult. Divers. Ethnic Minor. Psychol. 2011, 17, 234-242. [CrossRef] [PubMed]

12. Lott, B. The Social Psychology of Class and Classism. Am. Psychol. 2012, 67, 650-658. [CrossRef] [PubMed]

13. Goff, P.A.; Eberhardt, J.L.; Williams, M.J.; Jackson, M.C. Not yet Human: Implicit Knowledge, Historical Dehumanization, and Contemporary Consequences. J. Pers. Soc. Psychol. 2008, 94, 292-306. [CrossRef] [PubMed]

14. Loughnan, S.; Haslam, N.; Sutton, R.M.; Spencer, B. Dehumanization and Social Class: Animality in the Stereotypes of "White Trash", "Chavs" and "Bogans". Soc. Psychol. 2014, 45, 54-61. [CrossRef]

15. Cuddy, A.J.C.; Fiske, S.T.; Glick, P. The BIAS Map: Behaviors from Intergroup Affect and Stereotypes. J. Pers. Soc. Psychol. 2007, 92, 631-648. [CrossRef]

16. Baron, R.M.; Albright, L.; Malloy, T.E. Effects of Behavioral and Social Class Information on Social Judgment. Pers. Soc. Psychol. Bull. 1995, 21, 308-315. [CrossRef]

17. Russell, A.M.T.; Fiske, S.T. It's All Relative: Competition and Status Drive Interpersonal Perception. Eur. J. Soc. Psychol. 2008, 38, 1193-1201. [CrossRef]

18. Bertrand, M.; Mullainathan, S. Are Emily and Greg More Employable Than Lakisha and Jamal? A Field Experiment on Labor Market Discrimination. Am. Econ. Rev. 2004, 94, 991-1013. [CrossRef]

19. Rivera, L.A. Pedigree: How Elite Students Get Elite Jobs; Princeton University Press: Princeton, NJ, USA, 2016; ISBN 978-1-4008-8074-4. 
20. National Housing Law Project. Source of Income Discrimination. November 2017. Available online: https://www.nhlp.org/ resources / source-of-income-discrimination-2/ (accessed on 24 June 2021).

21. Housing Discrimination Against Racial and Ethnic Minorities 2012; U.S. Department of Housing and Urban Development: Washington, DC, USA, 2013; p. 190.

22. Rothstein, R. The Color of Law: A Forgotten History of How Our Government Segregated America; Liveright Publishing Corporation: New York, NY, USA, 2017; ISBN 978-1-63149-286-0.

23. Rothwell, J.T.; Massey, D.S. Density Zoning and Class Segregation in U.S. Metropolitan Areas*: Density Zoning and Class Segregation. Soc. Sci. Q. 2010, 91, 1123-1143. [CrossRef]

24. National Law Center on Homelessness \& Poverty. Housing Not Handcuffs 2019. 2019. Available online: http://nlchp.org/wpcontent/uploads/2019/12/HOUSING-NOT-HANDCUFFS-2019-FINAL.pdf (accessed on 21 June 2021).

25. Sen, A. Development as Freedom, 1st ed.; Oxford University Press: Oxford, UK, 1999; ISBN 9780198297581.

26. Yunus, M. A World of Three Zeros: The New Economics of Zero Poverty, Zero Unemployment and Zero Net Carbon Emissions; Public Affairs: New York, NY, USA, 2017; ISBN 978-1-5417-6792-8.

27. Amin, S. The Millennium Development Goals: A Critique from the South. Mon. Rev. 2006, 57, 1. [CrossRef]

28. Kroll, C. Sustainable Development Goals: Are the Rich Countries Ready? 2015. Available online: https://www.bertelsmannstiftung.de/en/publications/publication/did/sustainable-development-goals-are-the-rich-countries-ready/ (accessed on 24 June 2021).

29. Gupta, J.; Vegelin, C. Sustainable Development Goals and Inclusive Development. Int. Environ. Agreem. Polit. Law Econ. 2016, 16, 433-448. [CrossRef]

30. Dreier, P.; Swanstrom, T.; Mollenkopf, J. Economic Inequality and Public Policy: The Power of Place. City Community 2002, 1, 349-372. [CrossRef]

31. Mele, C. Casinos, Prisons, Incinerators, and Other Fragments of Neoliberal Urban Development. Soc. Sci. Hist. 2011, 35, 423-452. [CrossRef]

32. Brenner, N.; Theodore, N. Cities and the Geographies of "Actually Existing Neoliberalism". Antipode 2002, 34, 349-379. [CrossRef]

33. Peck, J.; Tickell, A. Neoliberalizing Space. Antipode 2002, 34, 380-404. [CrossRef]

34. Judt, T. Ill Fares the Land; The Penguin Press: New York, NY, USA, 2010.

35. Clarke, J. Dissolving the Public Realm? The Logics and Limits of Neo-Liberalism. J. Soc. Policy 2004, 33, 27-48. [CrossRef]

36. Center on Budget and Policy Priorities. Trump Budget Deeply Cuts Health, Housing, Other Assistance for Low- and ModerateIncome Families. 2018. Available online: https://www.cbpp.org/research/federal-budget/trump-budget-deeply-cuts-healthhousing-other-assistance-for-low-and (accessed on 24 June 2021).

37. Horsley, S. GOP Health Care Bill Would Cut About \$765 Billion In Taxes Over 10 Years. Available online: https:/ /www.npr.org/ 2017/05/04/526923181/gop-health-care-bill-would-cut-about-765-billion-in-taxes-over-10-years (accessed on 23 June 2021).

38. Executive Office of the President. Reducing Poverty in America by Promoting Opportunity and Economic Mobility. 2018. Available online: https:/ /www.federalregister.gov/documents/2018/04/13/2018-07874/reducing-poverty-in-america-bypromoting-opportunity-and-economic-mobility (accessed on 24 June 2021).

39. Shaw, K. Gentrification: What It Is, Why It Is, and What Can Be Done about It. Geogr. Compass 2008, 2, 1697-1728. [CrossRef]

40. Smith, N. The New Urban Frontier: Gentrification and the Revanchist City; Routledge: New York, NY, USA, 1996 ; ISBN 0203975642.

41. Mitchell, D. The End of Public Space? People's Park, Definitions of the Public, and Democracy. Ann. Assoc. Am. Geogr. 1995, 85, 108-133.

42. Low, S.M. The Erosion of Public Space and the Public Realm: Paranoia, Surveillance and Privatization in New York City. City Soc. 2006, 18, 43-49. [CrossRef]

43. Low, S.M. The Edge and the Center: Gated Communities and the Discourse of Urban Fear. Am. Anthropol. 2001, 103, 45-58. [CrossRef]

44. KSBW. Santa Cruz Installs High Pitch Noise Boxes along San Lorenzo River Levee. 2014. Available online: http:/ / www.ksbw. com/article/santa-cruz-installs-high-pitch-noise-boxes-along-san-lorenzo-river-levee/1054906 (accessed on 18 May 2018).

45. Zukin, S. Urban Lifestyles: Diversity and Standardisation in Spaces of Consumption. Urban Stud. 1998, 35, 825-839. [CrossRef]

46. Altman, I.; Rogoff, B. World views in psychology: Trait, interactional, organismic, and transactional perspectives. In Handbook of Environmental Psychology; Stokols, D., Altman, I., Eds.; Wiley: New York, NY, USA, 1987; pp. 1-40.

47. Heft, H. Chapter 1: William James's radical empiricism: A foundation for ecological psychology. In Ecological Psychology in Context: James Gibson, Roger Barker and the Legacy of William James's Radical Empiricism; Lawrence Erlbaum Associates, Inc.: Mahwah, NJ, USA, 2001.

48. Dewey, J. The Reflex Arc Concept In Psychology. J. Nerv. Ment. Dis. 1896, 3, 357-370. [CrossRef]

49. Adams, G.; Estrada-Villalta, S. Theory from the South: A Decolonial Approach to the Psychology of Global Inequality. Curr. Opin. Psychol. 2017, 18, 37-42. [CrossRef]

50. Adams, G.; Salter, P.S. Health Psychology in African Settings: A Cultural-Psychological Analysis. J. Health Psychol. 2007, 12, 539-551. [CrossRef]

51. Dewey, J. The Public and Its Problems; Swallow Press: Athens, Greece, 1991; ISBN 978-0-8040-0254-7. 
52. Cigna. Cigna U.S. Loneliness Index: Survey of 20,000 Americans Examining Behaviors Driving Loneliness in the United States. 2018. Available online: https:/ / www.multivu.com/players/English/8294451-cigna-us-loneliness-survey/docs/IndexReport_1524 069371598-173525450.pdf (accessed on 24 June 2021).

53. Cacioppo, S.; Capitanio, J.P.; Cacioppo, J.T. Toward a Neurology of Loneliness. Psychol. Bull. 2014, 140, 1464-1504. [CrossRef] [PubMed]

54. Murthy, V. Work and the Loneliness Epidemic. Harvard Business Review. 2017. Available online: https://hbr.org/2017/09/ work-and-the-loneliness-epidemic (accessed on 24 June 2021).

55. Kohn, M. Homo Spectator: Public Space in the Age of the Spectacle. Philos. Soc. Crit. 2008, 34, 467-486. [CrossRef]

56. Nafstad, H.E.; Blakar, R.M.; Carlquist, E.; Phelps, J.M.; Rand-Hendriksen, K. Globalization, Neo-Liberalism and Community Psychology. Am. J. Community Psychol. 2009, 43, 162-175. [CrossRef]

57. Harvey, D. A Brief History of Neoliberalism; Oxford University Press: New York, NY, USA, 2005.

58. Stiglitz, J.E. The Great Divide; W. W. Norton: New York, NY, USA, 2015; ISBN 978-0-393-35218-4.

59. Wolff, E.N. A Century of Wealth in America; The Belknap Press of Harvard University Press: Cambridge, MA, USA, 2017; ISBN 978-0-674-49514-2.

60. Stone, C.; Trisi, D.; Sherman, A.; Taylor, R.; Chen, W.; Debot, B.; Horton, E. A Guide to Statistics on Historical Trends in Income Inequality; Center on Budget and Policy Priorities: Washington, DC, USA, 2018.

61. Piketty, T.; Saez, E. Inequality in the Long Run. Science 2014, 344, 838-843. [CrossRef]

62. Horowitz, J.M.; Igielnik, R.; Kocchar, R. Trends in U.S. Income and Wealth Inequality; Pew Research Center: Washington, DC, USA, 2020.

63. Pew Research Center. The American Middle Class Is Losing Ground. 2015. Available online: https: / /www.pewresearch.org/ social-trends/2015/12/09/the-american-middle-class-is-losing-ground/ (accessed on 24 June 2021).

64. Shapiro, T. Wealth-The Stanford Center on Poverty and Inequality. 2017, pp. 36-38. Available online: https://inequality. stanford.edu/sites/default/files/Pathways_SOTU_2017_wealth.pdf (accessed on 24 June 2021).

65. Norton, M.I.; Ariely, D. Building a Better America-One Wealth Quintile at a Time. Perspect. Psychol. Sci. 2011, 6, 9-12. [CrossRef]

66. Pew Research Center. Beyond Distrust: How Americans View Their Government. 2015. Available online: https://www pewresearch.org/politics/2015/11/23/beyond-distrust-how-americans-view-their-government/ (accessed on 24 June 2021).

67. Pickett, K.E.; Wilkinson, R.G. Income Inequality and Health: A Causal Review. Soc. Sci. Med. 2015, 128, 316-326. [CrossRef]

68. Chetty, R.; Stepner, M.; Abraham, S.; Lin, S.; Scuderi, B.; Turner, N.; Bergeron, A.; Cutler, D. The Association Between Income and Life Expectancy in the United States, 2001-2014. JAMA 2016, 315, 1750. [CrossRef]

69. Wilkinson, R.; Pickett, K. The Hidden Key to Better Health and Higher Scores. Am. Educ. 2011, 35, 5-9.

70. Graham, C. The High Costs of Being Poor in America: Stress, Pain and Worry; Brookings Institute: Washington, DC, USA, 2015.

71. Hout, M. Money and Morale: Growing Inequality Affects How Americans View Themselves and Others. Ann. Am. Acad. Pol. Soc. Sci. 2016, 663, 204-228. [CrossRef]

72. Reardon, S. The Widening Academic Achievement Gap between the Rich and the Poor. Community Investig. 2012, $24,19$.

73. Duncan, G.J.; Murnane, R.J. Introduction: The American Dream, Then and Now. In Whither Opportunity?: Rising Inequality, Schools and Children's Life Chances; Russel Sage Foundation: New York, NY, USA, 2011; pp. 3-23. ISBN 978-1-61044-751-5.

74. Kaushal, N.; Magnuson, K.; Waldfogel, J. How is family income related to investments in children's learning? In Whither opportunity?: Rising Inequality, Schools and Children's Life Chances; Duncan, G.J., Murnane, R.J., Eds.; Russel Sage Foundation: New York, NY, USA, 2011; ISBN 978-1-61044-751-5.

75. Putnam, R.D. Bowling Alone: The Collapse and Revival of American Community, 1st ed.; Simon \& Schuster: New York, NY, USA, 2001; ISBN 978-0-7432-0304-3.

76. Twenge, J.M.; Campbell, W.K.; Carter, N.T. Declines in Trust in Others and Confidence in Institutions Among American Adults and Late Adolescents, 1972-2012. Psychol. Sci. 2014, 25, 1914-1923. [CrossRef] [PubMed]

77. Pastor, M.; Benner, C. Equity, Growth, and Community: What the Nation Can Learn from America's Metro Areas; University of California Press: Oakland, CA, USA, 2015; ISBN 978-0-520-28441-8.

78. Wilkinson, R.G.; Pickett, K. The Spirit Level: Why Greater Equality Makes Societies Stronger, 1st ed.; Bloomsbury Press: New York, NY, USA, 2010; ISBN 978-1-60819-341-7.

79. Pew Research Center. Political Polarization in the American Public. 2014. Available online: https://www.pewresearch.org/ politics /2014/06/12/political-polarization-in-the-american-public/ (accessed on 24 June 2021).

80. Pew Research Center. Public Trust in Government: 1958-2021. 2021. Available online: https://www.pewresearch.org/politics/ 2021/05/17/public-trust-in-government-1958-2021/ (accessed on 24 June 2021).

81. Gallup. Confidence in Institutions. 2020. Available online: https://news.gallup.com/poll/1597/confidence-institutions.aspx (accessed on 24 June 2021).

82. Mitchell, L.E. Stacked Deck; Temple University Press: Philadelphia, PA, USA, 1998; ISBN 978-1566395922.

83. Davidson, G.; Davidson, P. Economics for a Civilized Society; M.E. Sharpe: Armonk, NY, USA, 1996; ISBN 978-1-56324-893-1.

84. Kraus, M.W.; Côté, S.; Keltner, D. Social Class, Contextualism, and Empathic Accuracy. Psychol. Sci. 2010, 21, 1716-1723. [CrossRef]

85. Stellar, J.E.; Manzo, V.M.; Kraus, M.W.; Keltner, D. Class and Compassion: Socioeconomic Factors Predict Responses to Suffering. Emotion 2012, 12, 449-459. [CrossRef] 
86. Piff, P.K.; Stancato, D.M.; Cote, S.; Mendoza-Denton, R.; Keltner, D. Higher Social Class Predicts Increased Unethical Behavior. Proc. Natl. Acad. Sci. USA 2012, 109, 4086-4091. [CrossRef]

87. Uslaner, E.M. Divided Citizens: How Inequality Undermines Trust in America; Demos: New York, NY, USA, 2004.

88. Sorkin, A.R.; Thee-Brenan, A.R.S. Many Feel the American Dream Is Out of Reach, Poll Shows. The New York Times 10 December 2014. Available online: https:/ / dealbook.nytimes.com/2014/12/10/many-feel-the-american-dream-is-out-of-reach-poll-shows / (accessed on 23 June 2021).

89. Morin, R. Rising Share of Americans See Conflict Between Rich and Poor; Pew Research Center: Washington, DC, USA, 2012. Available online: https:/ / www.pewresearch.org/social-trends/2012/01/11/rising-share-of-americans-see-conflict-between-rich-andpoor/ (accessed on 24 June 2021).

90. Carl, N.; Billari, F.C. Generalized Trust and Intelligence in the United States. PLoS ONE 2014, 9, e91786. [CrossRef]

91. Dorling, D. The Equality Effect: Improving Life for Everyone; New Internationalist Publications Ltd: Oxford, UK, 2017; ISBN 978-1-78026-390-8.

92. Islam, S.N. Inequality and Environmental Sustainability; Working Paper 145; Department of Economic \& Social Affairs, 2015. Available online: https://www.un.org/esa/desa/papers/2015/wp145_2015.pdf (accessed on 24 June 2021).

93. Mikkelson, G.M.; Gonzalez, A.; Peterson, G.D. Economic Inequality Predicts Biodiversity Loss. PLoS ONE 2007, 2, e444. [CrossRef]

94. Gore, T. Confronting Carbon Inequality: Putting Climate Justice at the Heart of the COVID-19 Recovery; Oxfam: Nairobi, Kenya, 2020; Available online: https:/ /www.oxfam.org/en/research/confronting-carbon-inequality (accessed on 24 June 2021).

95. Griffin, P. The Carbon Majors Database: CDP Carbon Majors Report 2017; CDP: London, UK, 2017; p. 16. Available online: https:/ / 6fefcbb86e61af1b2fc4-c70d8ead6ced550b4d987d7c03fcdd1d.ssl.cf3.rackcdn.com/cms/reports/documents /000/002 / 327/ original/Carbon-Majors-Report-2017.pdf?1501833772 (accessed on 24 June 2021).

96. Goldstein, B.; Gounaridis, D.; Newell, J.P. The Carbon Footprint of Household Energy Use in the United States. Proc. Natl. Acad. Sci. USA 2020, 117, 19122-19130. [CrossRef]

97. Moser, S.; Kleinhückelkotten, S. Good Intents, but Low Impacts: Diverging Importance of Motivational and Socioeconomic Determinants Explaining Pro-Environmental Behavior, Energy Use, and Carbon Footprint. Environ. Behav. 2018, 50, 626-656. [CrossRef]

98. Mendelsohn, R.; Dinar, A.; Williams, L. The Distributional Impact of Climate Change on Rich and Poor Countries. Environ. Dev. Econ. 2006, 11, 159-178. [CrossRef]

99. Islam, S.N.; Winkel, J. Climate Change and Social Inequality; Working Paper 152; Department of Economic \& Social Affairs, 2017. Available online: https://www.un.org/esa/desa/papers/2017/wp152_2017.pdf (accessed on 24 June 2021).

100. Morello-Frosch, R.; Pastor, M.; Porras, C.; Sadd, J. Environmental Justice and Regional Inequality in Southern California: Implications for Future Research. Environ. Health Perspect. 2002, 110, 149-154. [CrossRef] [PubMed]

101. Woo, B.; Kravitz-Wirtz, N.; Sass, V.; Crowder, K.; Teixeira, S.; Takeuchi, D.T. Residential Segregation and Racial/Ethnic Disparities in Ambient Air Pollution. Race Soc. Probl. 2019, 11, 60-67. [CrossRef]

102. Pulido, L. Geographies of Race and Ethnicity II: Environmental Racism, Racial Capitalism and State-Sanctioned Violence. Prog. Hum. Geogr. 2017, 41, 524-533. [CrossRef]

103. Pulido, L. Rethinking Environmental Racism: White Privilege and Urban Development in Southern California. Ann. Assoc. Am. Geogr. 2000, 90, 12-40. [CrossRef]

104. Estrada-Villalta, S.; Adams, G. Decolonizing Development: A Decolonial Approach to the Psychology of Economic Inequality. Transl. Issues Psychol. Sci. 2018, 4, 198-209. [CrossRef]

105. Stephens, N.M.; Fryberg, S.A.; Markus, H.R. When Choice Does Not Equal Freedom: A Sociocultural Analysis of Agency in Working-Class American Contexts. Soc. Psychol. Personal. Sci. 2011, 2, 33-41. [CrossRef]

106. Stephens, N.M.; Fryberg, S.A.; Markus, H.R.; Johnson, C.S.; Covarrubias, R. Unseen Disadvantage: How American Universities' Focus on Independence Undermines the Academic Performance of First-Generation College Students. J. Pers. Soc. Psychol. 2012, 102, 1178-1197. [CrossRef] [PubMed]

107. Domhoff, G.W. Power in America: Wealth, Income, and Power. Available online: https://whorulesamerica.ucsc.edu/po-wer/ wealth.html (accessed on 23 June 2021).

108. Solt, F. Economic Inequality and Democratic Political Engagement: Economic Inequality and Political Engagement. Am. J. Polit. Sci. 2008, 52, 48-60. [CrossRef]

109. Mahler, V.A.; Jesuit, D.K.; Paradowski, P.R. Electoral Turnout and State Redistribution: A Cross-National Study of Fourteen Developed Countries. Polit. Res. Q. 2014, 67, 361-373. [CrossRef]

110. Desilver, D. In Past Elections, U.S. Trailed Most Developed Countries in Voter Turnout; Pew Research Center: Washington, DC, USA, 2020. Available online: https://www.pewresearch.org/fact-tank/2020/11/03/in-past-elections-u-s-trailed-most-developedcountries-in-voter-turnout/ (accessed on 28 June 2021).

111. Leighley, J.E.; Nagler, J. Who Votes Now? Demographics, Issues, Inequality and Turnout in the United States; Princeton University Press: Princeton, NJ, USA, 2014; ISBN 978-0-691-15934-8.

112. U.S. Census Bureau. Voting and Registration in the Election of November 2020. 2021. Available online: https:/ /www.census. gov / data/tables/time-series/demo/voting-and-registration/p20-585.html (accessed on 24 June 2021).

113. Schlozman, K.L.; Verba, S.; Brady, H.E. The Unheavenly Chorus: Unequal Political Voice and the Broken Promise of American Democracy; Princeton University Press: Princeton, NJ, USA; Oxford, UK, 2012; ISBN 978-0-691-15484-8. 
114. Gilens, M. Affluence and Influence: Economic Inequality and Political Power in America; Princeton University Press: Princeton, NJ, USA, 2012; ISBN 9781400844821.

115. Pew Research Center. The Public, the Political System and American Democracy; Pew Research Center: Washington, DC, USA, 2018.

116. Pew Research Center. Government Gets Lower Ratings for Handling Health Care, Environment, Disaster Response; Pew Research Center: Washington, DC, USA, 2017.

117. Page, B.I.; Bartels, L.M.; Seawright, J. Democracy and the Policy Preferences of Wealthy Americans. Perspect. Polit. 2013, 11, 51-73. [CrossRef]

118. Bartels, L.M. Unequal Democracy: The Political Economy of the New Gilded Age, 2nd ed.; Russell Sage Foundation: New York, NY, USA, 2016; ISBN 978-0-691-17284-2.

119. Reich, R.B. Saving Capitalism: For the Many, Not the Few, 1st ed.; Alfred A. Knopf: New York, NY, USA, 2015; ISBN 978-0-385-35057-0.

120. Foa, R.S.; Mounk, Y. The Signs of Deconsolidation. J. Democr. 2017, 28, 5-15. [CrossRef]

121. Foa, R.S.; Mounk, Y. The Democratic Disconnect. J. Democr. 2016, 27, 5-17. [CrossRef]

122. Bermeo, N. Does Electoral Democracy Boost Economic Equality? J. Democr. 2009, 20, 21-35. [CrossRef]

123. Ethan, B.K. Nathan Converse Why Democracies Fail. J. Democr. 2008, 19, 57-68. [CrossRef]

124. Reardon, S.F.; Bischoff, K. The Continuing Increase in Income Segregation, 2007-2012; Stanford Center for Education Policy Analysis: Stanford, CA, USA, 2016.

125. Chawla, L.; Heft, H. Children's Competence and the Ecology of Communities: A Functional Approach to the Evaluation of Participation. J. Environ. Psychol. 2002, 22, 201-216. [CrossRef]

126. Shinn, M. Community Psychology and the Capabilities Approach. Am. J. Community Psychol. 2015, 55, 243-252. [CrossRef] [PubMed]

127. Toolis, E.E. Theorizing Critical Placemaking as a Tool for Reclaiming Public Space. Am. J. Community Psychol. 2017, 59, 184-199. [CrossRef] [PubMed]

128. Arfken, M. Marxism as a Foundation for Critical Social Psychology. In The Palgrave Handbook of Critical Social Psychology; Gough, B., Ed.; Palgrave Macmillan: London, UK, 2017; pp. 37-58. ISBN 978-1-137-51017-4.

129. Harvey, D. The Urban Process under Capitalism: A Framework for Analysis. Int. J. Urban Reg. Res. 1978, 2, 101-131. [CrossRef]

130. Dirlik, A. Place-Based Imagination: Globalism and the Politics of Place. Rev. Fernand Braudel Cent. 1999, 22, $151-187$.

131. Drury, J.; Reicher, S. Explaining Enduring Empowerment: A Comparative Study of Collective Action and Psychological Outcomes. Eur. J. Soc. Psychol. 2005, 35, 35-58. [CrossRef]

132. Chavis, D.M.; Wandersman, A. Sense of Community in the Urban Environment: A Catalyst for Participation and Community Development. In A Quarter Century of Community Psychology; Revenson, T.A., D'Augelli, A.R., French, S.E., Hughes, D.L., Livert, D., Seidman, E., Shinn, M., Yoshikawa, H., Eds.; Springer: Boston, MA, USA, 2002; pp. 265-292. ISBN 978-0-306-46730-1.

133. Fisher, E.L. Trusting Communities and Bigger In-Groups: Social Capital, Interracial Contact Climate, and Common In-Group Categorization: Social Capital, Contact, and Categorization. Anal. Soc. Issues Public Policy 2015, 15, 20-43. [CrossRef]

134. Christens, B.D. Toward Relational Empowerment. Am. J. Community Psychol. 2012, 50, 114-128. [CrossRef]

135. Whyte, W.H. The Social Life of Small Urban Spaces; Conservation Foundation: Washington, DC, USA, 1980; ISBN 978-0-89164-057-8.

136. Strydom, W.; Puren, K.; Drewes, E. Exploring Theoretical Trends in Placemaking: Towards New Perspectives in Spatial Planning. J. Place Manag. Dev. 2018, 11, 165-180. [CrossRef]

137. Arefi, M. Deconstructing Placemaking: Needs, Opportunities, and Assets; Routledge: Oxon, UK, 2014; ISBN 978-0-415-72436-4.

138. Schneekloth, L.H.; Shibley, R.G. Placemaking: The Art and Practice of Building Communities; Wiley: New York, NY, USA, 1995; ISBN 978-0-471-11026-2.

139. Fincher, R.; Pardy, M.; Shaw, K. Place-Making or Place-Masking? The Everyday Political Economy of "Making Place". Plan. Theory Pract. 2016, 17, 516-536. [CrossRef]

140. New York Times. How Statues Are Falling Around the World. 2020. Available online: https://www.nytimes.com/2020/06/24 /us / confederate-statues-photos.html (accessed on 23 June 2021).

141. About Paper Monuments. Available online: https:/ / www.papermonuments.org/aboutus (accessed on 23 June 2021).

142. Conaty, P.; Large, M. Commons Sense: Co-Operative Place Making and the Capturing of Land Value for 21st Century Garden Cities; Co-Operatives UK Limited: Machester, UK, 2013. Available online: https://ccednet-rcdec.ca/sites/ccednet-rcdec.ca/files/ commons_sense.pdf (accessed on 24 June 2021).

143. Saegert, S. Interrupting Inequality: Crisis and Opportunity in Low-Income Housing Policy. Metropolitics 2015.

144. Dudley Street Neighborhood Initiative. Our Mission. Available online: https://www.dsni.org/about-us (accessed on 23 June 2021).

145. Rebar. The Park(Ing) Day Manual. 2011. Available online: https://www.asla.org/uploadedFiles/CMS/Events/Parking_Day_ Manual_Consecutive.pdf (accessed on 24 June 2021).

146. Green Guerillas. Our History. Available online: https:/ /www.greenguerillas.org/history (accessed on 24 June 2021).

147. Ron Finley Project. About. 2021. Available online: https://ronfinley.com/pages/about (accessed on 24 June 2021).

148. Street Lab. The Uni Project: Make a Place for Learning. Available online: https://www.streetlab.org/uni-project/ (accessed on 23 June 2021). 
149. Planning Out. LGBT+ Placemaking Toolkit. 2019. Available online: https://res.cloudinary.com/fieldfisher/image/upload/v1 574347193/PDF-Files/PDFs\%20from\%20old\%20website/planning-out-placemaking-toolkit-2019_vxjryp.pdf (accessed on 23 June 2021).

150. Hansman, H. New York City Is Paying Public Housing Residents to Paint Murals, Smithsonian Magazine. 2016. Available online: https:/ / www.smithsonianmag.com/innovation/new-york-city-paying-public-housing-residents-paint-murals-1809 57913 / (accessed on 23 June 2021).

151. The City Repair Project. Placemaking Projects. Available online: https:/ / cityrepair.org/ our-projects (accessed on 23 June 2021 ).

152. McClean, S.; Onyx, J. Institutions and Social Change: Implementing Co-Operative Housing and Environmentally Sustainable Development at Christie Walk. Cosmop. Civ. Soc. Interdiscip. J. 2009, 1, 109-131. [CrossRef]

153. Markusen, A.; Gadwa, A. Creative Placemaking: Executive Summary; National Endowment for the Arts: Washington, DC, USA, 2010.

154. Webb, D. Placemaking and Social Equity: Expanding the Framework of Creative Placemaking. Artivate 2014, 3, 35-48. 